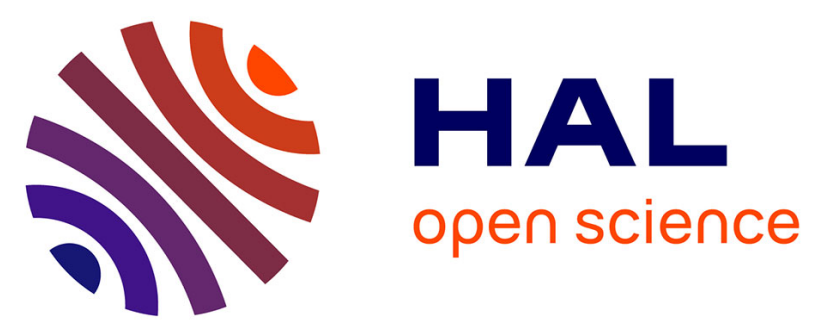

\title{
Prevalence of Hepatitis E virus specific antibodies in sera of German domestic pigs estimated by using different assays
}

Christine Baechlein, Anika Schielke, Reimar Johne, Rainer G. Ulrich, Wolfgang Baumgaertner, Beatrice Grummer

\section{To cite this version:}

Christine Baechlein, Anika Schielke, Reimar Johne, Rainer G. Ulrich, Wolfgang Baumgaertner, et al.. Prevalence of Hepatitis E virus specific antibodies in sera of German domestic pigs estimated by using different assays. Veterinary Microbiology, 2010, 144 (1-2), pp.187. 10.1016/j.vetmic.2009.12.011. hal-00597832

\section{HAL Id: hal-00597832 \\ https://hal.science/hal-00597832}

Submitted on 2 Jun 2011

HAL is a multi-disciplinary open access archive for the deposit and dissemination of scientific research documents, whether they are published or not. The documents may come from teaching and research institutions in France or abroad, or from public or private research centers.
L'archive ouverte pluridisciplinaire HAL, est destinée au dépôt et à la diffusion de documents scientifiques de niveau recherche, publiés ou non, émanant des établissements d'enseignement et de recherche français ou étrangers, des laboratoires publics ou privés. 


\section{Accepted Manuscript}

Title: Prevalence of Hepatitis E virus specific antibodies in sera of German domestic pigs estimated by using different assays

Authors: Christine Baechlein, Anika Schielke, Reimar Johne, Rainer G. Ulrich, Wolfgang Baumgaertner, Beatrice Grummer

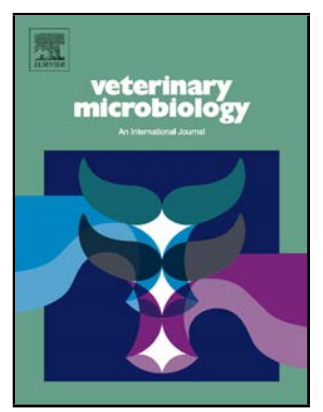

PII:

DOI: S0378-1135(09)00602-6

Reference: doi:10.1016/j.vetmic.2009.12.011

To appear in: $\quad$ VETMIC

Received date: 22-9-2009

Revised date: 1-12-2009

Accepted date: $\quad 3-12-2009$

Please cite this article as: Baechlein, C., Schielke, A., Johne, R., Ulrich, R.G., Baumgaertner, W., Grummer, B., Prevalence of Hepatitis E virus specific antibodies in sera of German domestic pigs estimated by using different assays, Veterinary Microbiology (2008), doi:10.1016/j.vetmic.2009.12.011

This is a PDF file of an unedited manuscript that has been accepted for publication. As a service to our customers we are providing this early version of the manuscript. The manuscript will undergo copyediting, typesetting, and review of the resulting proof before it is published in its final form. Please note that during the production process errors may be discovered which could affect the content, and all legal disclaimers that apply to the journal pertain. 
1 Prevalence of Hepatitis E virus-specific antibodies in sera of German domestic 2 pigs estimated by using different assays

3

4 Christine Baechlein ${ }^{1}$, Anika Schielke ${ }^{2}$, Reimar Johne ${ }^{2}$, Rainer G. Ulrich ${ }^{3}$, Wolfgang $5 \quad$ Baumgaertner ${ }^{4}$, Beatrice Grummer ${ }^{1^{*}}$

6

$7{ }^{1}$ Institute of Virology, Department of Infectious Diseases, University of Veterinary

8 Medicine Hannover, Buenteweg 17, 30559 Hannover, Germany

$9 \quad$ 2Federal Institute for Risk Assessment, Diedersdorfer Weg 1, 12277 Berlin, Germany

$10{ }^{3}$ Friedrich-Loeffler-Institut, Institute for Novel and Emerging Infectious Diseases,

11 Suedufer 10, 17493 Greifswald - Insel Riems, Germany

$12{ }^{4}$ Department of Pathology, University of Veterinary Medicine Hannover,

13 Buenteweg 17, 30559 Hannover, Germany

14

$15{ }^{*}$ corresponding author:

16 Tel.: +49-511-953-8845

17 fax: $+49-511-953-8898$

18 beatrice.grummer@tiho-hannover.de 


\section{Abstract}

22 Hepatitis $\mathrm{E}$ virus is the causative agent of an acute hepatitis in humans. In 23 industrialized countries, autochthonous hepatitis E cases in the past were mainly of 24 undetermined origin, whereupon nowadays some cases may be linked to zoonotic transmission of HEV from pigs and wild boars. In contrast to several European countries the HEV status of German domestic pigs and a possible risk of transmission are unknown so far. Here, a novel peptide-based ELISA was used to detect HEV-specific antibodies in 1072 sera from German domestic pigs resulting in an average seroprevalence of $49.8 \%$ indicating widespread HEV infections in these animals. A comparative testing of 321 randomly selected sera revealed a seroprevalence of $64.8 \%$ when using a commercially available ELISA and $43.9 \%$ for the novel peptide-based ELISA but concordant results were obtained in both tests only for $56.1 \%$ of the sera. Additional re-testing of 23 randomly selected sera with a modified commercially available immunoblot revealed discordant results also. The use of different antigens and the measurement of different immunoglobulin classes are considered to be responsible for the observed variations of the results. Though the present study revealed a high seroprevalence of HEV in the German domestic pig population and a potential risk of transmission to humans, the differing results of the tests highlight the necessity of a standardization of serological assays for comparative seroprevalence and longitudinal studies.

Keywords: Hepatitis E virus, pigs, antibody assays 


\section{Introduction}

Hepatitis E virus (HEV) is a non-enveloped, single-stranded RNA virus mostly causing a mild to moderate self-limiting hepatitis in humans. The positively orientated RNA genome possesses three open reading frames (ORFs), which code for the nonstructural proteins (ORF1), the capsid protein (ORF2) and a phosphoprotein that is associated with the cytoskeleton (ORF3) (Zafrullah et al., 1997).

In developing countries, where HEV is endemic, the virus is transmitted to humans via contaminated drinking water and mostly affects adults. In Europe, numerous symptomatic hepatitis E cases without a travelling history to HEV-endemic regions were reported in the previous years (Buti et al., 2004; Mansuy et al., 2004; Wichmann et al., 2008). The assumption of domestic pigs and wild boar representing HEV reservoirs in industrial countries was confirmed by the detection of HEV-specific RNA and antibodies in these animals (Rutjes et al., 2007; de Deus et al., 2008; Di Bartolo et al., 2008; McCreary et al., 2008).

HEV is representing a unique serotype (Anderson et al., 1999), but is subgrouped into at least four different genotypes. Genotype 1 and 2 occur in humans only and can be found in Southeast Asia, Mexico and Central Africa, respectively (Schlauder and Mushahwar, 2001). HEV genotype 3 and 4 can be found in humans and pigs (Purcell and Emerson, 2008).

Although HEV obviously circulates in the German wild boar population at least for the last fourteen years (Kaci et al., 2008; Adlhoch et al., 2009; Schielke et al., 2009), studies on domestic pigs were still pending.

Here, we report on the application of a novel peptide-based ELISA for a seroprevalence study in German domestic pigs. The absolute values of the generally high HEV seroprevalences differed between the novel ELISA and two commercially 
available tests. We discuss the possible reasons for the variation of results and suggest a standardization of test systems for future seroepidemiological studies.

\section{Materials and Methods}

Serum samples. A total of 1,072 sera were randomly collected from 142 farms of ten federal states of Germany during 2007/2008. For 264 sera data on the age of the pigs were available. Positive and negative reference field sera from domestic pigs from Spain had been previously characterized using an HEV genotype 1 ELISA (Martin et al., 2007; sera were kindly provided by M. Casas, CReSA, Barcelona, Spain).

Novel peptide-based ELISA (TiHo-ELISA). The newly developed ELISA (TiHoELISA) is based on a synthetic peptide representing a composite of carboxy-terminal 30 amino acid (aa) residues of ORF 2 protein and carboxy-terminal 29 aa residues of ORF 3 protein, both originating from the Burmese HEV genotype 1 strain (Tam et al., 1991). Ninety-six well plates were coated with these HEV ORF2/ORF3 peptides purchased from Acris Antibodies GmbH (Herford, Germany). Sera were applied in a dilution of 1:250 in phosphate buffered saline (PBS) with 1\% horse serum. After a stringent wash with $3 \mathrm{M}$ urea, polyclonal rabbit anti-pig IgG conjugated with horseradish peroxidase (Sigma-Aldrich, Saint Louis, USA) was used in a dilution of 1:10,000. As substrate, tetramethylbenzidine (TMB) was added for 10 minutes followed by stopping of the enzymatic reaction with $1 \mathrm{M}$ hydrochloric acid. The optical density (OD) was automatically scored in an ELISA reader (Tecan Sunrise, Tecan, Crailsheim, Germany). 
94 Commercial recombinant protein-based ELISA (Axiom-ELISA). The commercially available HEV Ab-ELISA kit (Axiom, Bürstadt, Germany) is a double-antigen sandwich ELISA based on a recombinant Burmese HEV genotype 1 capsid protein derivative covering the carboxy-terminal aa residues 394 to 606 . Due to its test principle, it can detect HEV-specific antibodies independently of the host species and immunoglobulin class. The assay was performed by strictly following the manufacturer's instructions including the recommended thresholds for definition of a positive serum.

\section{Commercial immunoblot test. The recomBlot test (Mikrogen, Neuried, Germany),} primarily developed for the detection of anti-HEV antibodies in human serum, bases on four recombinant proteins of HEV genotype 1: three overlapping ORF2 derived polypeptides that completely cover the capsid protein and the entire ORF3 protein. This test was performed following the recommendations of the manufacturer with the following modifications: sera at a dilution of 1:200 were incubated with the blot strips for two hours. After washing, peroxidase-conjugated polyclonal rabbit anti-pig IgG (Sigma-Aldrich, Saint Louis, USA) was used to detect specific antibodies. TMB was used as substrate for up to 15 minutes. The results were defined as positive (strong bands visible), equivocal (weak bands visible) or negative (no band visible).

\section{Results}

Testing of domestic pig sera with the TiHo-ELISA. For the new ELISA, a cut-off value was defined using four negative control sera as defined by Martin et al., 2007. These sera also reacted negative in the two commercial tests used in our study. The cut-off value resulted from the average ODs of up to 27 testings of these negative 
120 controls plus a threefold standard deviation. Two positive reference sera, which have

121 also been confirmed by the immunoblot test and the Axiom-ELISA to contain anti-

122 HEV antibodies, showed OD values well above the calculated cut-off value in the

123 TiHo-ELISA in multiple investigations. For all subsequent investigations one of the

124 negative and both positive controls were applied on each plate (Fig. 1). To reduce

125 background reactions and to identify antibodies with high avidity an additional

126 incubation step with 3M urea was applied.

127 In total, 1,072 porcine serum samples have been screened and about half of the sera

$128(534=49.8 \%)$ were tested positive in the TiHo-ELISA. The seroprevalence in the

129 different federal states ranged from 15.6\% in Mecklenburg-Western Pomerania to

$13070.7 \%$ in Bavaria. In 111 of 142 investigated farms (78.2\%) at least one anti-HEV

131 antibody-positive animal was identified with all farms in Bavaria and Baden-

132 Wuerttemberg being affected (Table 1). Additional information about gender or age of

133 the pigs was available for 264 samples. The prevalence in the adult females and

134 males was $50 \%$ or close to $50 \%$, respectively, but lower in the younger animals,

135 whereas the average prevalence in the whole investigated panel was about $30 \%$

136 (Table 2).

137

138 Comparison of the TiHo-ELISA with the Axiom-ELISA. To verify the results of the

139 TiHo-ELISA, 321 randomly chosen field sera, representing the minimum sample

140 number for comparison as calculated for a $95 \%$ confidence level and a $5 \%$

141 confidence interval (http://www.surveysystem.com/sscalc.htm), were analysed in

142 parallel with the Axiom-ELISA. This test classified $208(64.8 \%)$ of the samples as

143 positive. Using the same set of samples, the TiHo-ELISA rated $141(43.9 \%)$ of the

144 sample as positive (Table 3). A closer analysis of the results revealed that only 180 
$145(56.1 \%)$ of the analysed sera showed identical results in both tests. The kappa-value

146 was calculated as 0.182 showing only slight concordance between both ELISA tests.

148 Comparison of ELISA results with immunoblot data. Further investigations of 23

149 randomly selected sera were done with the modified recomBlot test. The sera were

150 chosen because of their reactivity in the TiHo-ELISA: 12 anti-HEV positive and 11

151 anti-HEV negative sera of differing origin were included. In this test, five sera reacted

152 positive, six sera were classified as equivocal and 12 sera didn't show any reactivity

153 with one of the recombinant proteins. In conclusion, seven (30.4\%) of the sera

154 revealed identical results in all three tests (Table 4). Unfortunately, we couldn't test a

155 larger number of sera, because the manufacturer discontinued the production of the 156 test.

\section{Discussion}

159 There is increasing evidence that hepatitis $E$ is a zoonosis. Pigs, either domestic or

160 feral, can be infected with HEV and phylogenetic analyses revealed a geographical

161 clustering of porcine and human HEV strains indicating a molecular epidemiological evidence for pig to human HEV transmission. In this study, we show that HEV is widespread in the German domestic pig population as previously reported also for HEV in wild boars (Kaci et al., 2008; Adlhoch et al., 2009; Schielke et al., 2009). These data are in line with high seroprevalences observed in domestic pigs from

166 Spain and France (Seminati et al., 2008; Casas et al., 2009; Kaba et al., 2009). In

167 Europe, Germany plays a major role in the pig meat production, and it is known that sporadic cases or limited outbreaks of hepatitis $\mathrm{E}$ can be related to the consumption of undercooked HEV containing wild boar meat (Matsuda et al., 2003). Besides

170 demonstrating a high HEV seroprevalence, the TiHo-ELISA also revealed that HEV- 
171 specific antibodies are common in all age groups of pigs but with only a small portion

172 of piglets exhibiting anti-HEV antibodies. Most of the serum samples from piglets

173 originated from Lower Saxony where the general seroprevalence is relatively low.

174 Therefore further analyses in different federal states seem to be necessary.

175 Additionally, the farming structure may contribute to the recording of differing

176 seroprevalences between the federal states. In Baden-Wuerttemberg and Bavaria,

177 where the highest anti-HEV prevalences were recorded, the piggeries are generally

178 smaller with less structuring of pig production, which is probably also related to

179 inefficient disinfection of stables or to potential contact to wild boars.

180 Analyses with another ELISA and with a commercial immunoblot confirmed the high

181 seroprevalence of HEV in German pigs; however a closer examination of the test

182 results revealed that both ELISAs and the immunoblot test disaccorded strongly.

183 Several conceivable explanations are possible for this observation. All three tests

184 base on polypeptides of HEV genotype 1, but different regions of the immunogenic

185 proteins were presented as antigens. The TiHo-ELISA and the Axiom-ELISA use

186 antigens corresponding to the carboxy-terminal region of the capsid protein but of

187 different size. The immunoblot test uses polypeptides completely covering ORF2 and

188 ORF3 proteins, but in a denatured form. The presence of antibodies with different

189 binding specificities to the HEV polypeptides may therefore influence the test result.

190 Furthermore, the Axiom-ELISA was developed for the simultaneous detection of

191 antibodies of all classes. In contrast, the TiHo-ELISA and the modified immunoblot

192 test detect porcine IgG antibodies only. The presence of IgM in sera from acutely

193 infected pigs and IgG in sera from reconvalescent pigs may therefore also explain

194 contradictory results using the different test systems.

195 Besides, the inclusion of an incubation step with 3M urea in the TiHo-ELISA protocol

196 dropped background reactions remarkably resulting in the detection of exclusively 
197 antibodies with high avidity to the antigen. This phenomenon was revealed by

198 Allmang et al., 2001, who showed that in horses naturally infected with Borna

199 disease virus, IgG with high avidity to the viral nucleoprotein could be selected by

200 treatment with urea. Varying results using different assays to determine the HEV

201 seroprevalence in pigs have also been reported previously (Peralta et al., 2009)

202 showing that there is an urgent need for standardized serological assays for the 203 detection of HEV-specific antibodies in pigs in general. Comparability of assays may 204 for example be achieved by the use of homologous porcine sequences of HEV genotype 3 as it has been proposed by others (Jimenez de Oya et al., 2009; Peralta et al., 2009). Such assays will be needed to enable comparison of results of surveillance studies conducted by independent research groups in different countries and also for reliable testing results in order to define a distinct pig farm as free from HEV.

\section{Acknowledgments:}

212 For providing us with field sera we would like to thank Ursula Biesenbach

213 (Neumünster, Germany), Jens Böttcher (Poing, Germany), Claudia Bunzenthal 214 (Krefeld, Germany), Klaus Dräger (Koblenz, Germany), Frerk Feldhusen and Marlis 215 Klopries (Rostock, Germany), Wolgang Gaede (Stendal, Germany), Andreas Hlinak 216 (Frankfurt/Oder, Germany), Thomas Miller (Aulendorf, Germany), Eva Nerbas

217 (Hannover, Germany), Katja Sachs (Bad Langensalza, Germany) and Bernd218 Andreas Schwarz (Leipzig, Germany). R. G. Ulrich kindly acknowledges Paul Dremsek (Riems, Germany) for helpful comments. 


\section{References:}

224 Adlhoch, C., Wolf, A., Meisel, H., Kaiser, M., Ellerbrok, H., Pauli, G., 2009. High HEV presence in four different wild boar populations in East and West Germany. Vet Microbiol. 139, 270-278.

Allmang, U., Hofer, M., Herzog, S., Bechter, K., Staeheli, P., 2001. Low avidity of human serum antibodies for Borna disease virus antigens questions their diagnostic value. Mol Psychiatry. 6, 329-333.

Anderson, D.A., Li, F., Riddell, M., Howard, T., Seow, H.F., Torresi, J., Perry, G., antibody to hepatitis E virus based on a highly conserved, conformational epitope expressed in Escherichia coli. J Virol Methods. 81, 131-142.

Buti, M., Clemente-Casares, P., Jardi, R., Formiga-Cruz, M., Schaper, M., Valdes, A., Rodriguez-Frias, F., Esteban, R., Girones, R., 2004. Sporadic cases of acute autochthonous hepatitis E in Spain. J Hepatol. 41, 126-131.

Casas, M., Pujols, J., Rosell, R., de Deus, N., Peralta, B., Pina, S., Casal, J., Martin, M., 2009. Retrospective serological study on hepatitis $E$ infection in pigs from 1985 to 1997 in Spain. Vet Microbiol. 135, 248-252.

de Deus, N., Peralta, B., Pina, S., Allepuz, A., Mateu, E., Vidal, D., Ruiz-Fons, F., Martin, M., Gortazar, C., Segales, J., 2008. Epidemiological study of hepatitis E virus infection in European wild boars (Sus scrofa) in Spain. Vet Microbiol. $129,163-170$.

Di Bartolo, I., Martelli, F., Inglese, N., Pourshaban, M., Caprioli, A., Ostanello, F., Ruggeri, F.M., 2008. Widespread diffusion of genotype 3 hepatitis E virus among farming swine in Northern Italy. Vet Microbiol. 132, 47-55.

Jimenez de Oya, N., Galindo, I., Girones, O., Duizer, E., Escribano, J.M., Saiz, J.C., 2009. Serological immunoassay for detection of hepatitis $E$ virus on the basis 
of genotype 3 open reading frame 2 recombinant proteins produced in Trichoplusia ni larvae. J Clin Microbiol. 47, 3276-3282.

251

252

Kaba, M., Davoust, B., Marie, J.L., Barthet, M., Henry, M., Tamalet, C., Raoult, D., Colson, P., 2009. Frequent transmission of hepatitis $E$ virus among piglets in farms in Southern France. J Med Virol. 81, 1750-1759.

Kaci, S., Nockler, K., Johne, R., 2008. Detection of hepatitis E virus in archived German wild boar serum samples. Vet Microbiol. 128, 380-385.

Mansuy, J.M., Peron, J.M., Abravanel, F., Poirson, H., Dubois, M., Miedouge, M., Vischi, F., Alric, L., Vinel, J.P., Izopet, J., 2004. Hepatitis E in the south west of France in individuals who have never visited an endemic area. J Med Virol. 74, 419-424.

Martin, M., Segales, J., Huang, F.F., Guenette, D.K., Mateu, E., de Deus, N., Meng, X.J., 2007. Association of hepatitis E virus (HEV) and postweaning multisystemic wasting syndrome (PMWS) with lesions of hepatitis in pigs. Vet Microbiol. 122, 16-24.

Matsuda, H., Okada, K., Takahashi, K., Mishiro, S., 2003. Severe hepatitis E virus infection after ingestion of uncooked liver from a wild boar. J Infect Dis. 188, 944.

McCreary, C., Martelli, F., Grierson, S., Ostanello, F., Nevel, A., Banks, M., 2008. Excretion of hepatitis $\mathrm{E}$ virus by pigs of different ages and its presence in slurry stores in the United Kingdom. Vet Rec. 163, 261-265.

Peralta, B., Casas, M., de Deus, N., Martin, M., Ortuno, A., Perez-Martin, E., Pina, S., Mateu, E., 2009. Anti-HEV antibodies in domestic animal species and rodents from Spain using a genotype 3-based ELISA. Vet Microbiol. 137, 66-73.

Purcell, R.H., Emerson, S.U., 2008. Hepatitis E: an emerging awareness of an old disease. J Hepatol. 48, 494-503. 
275 Rutjes, S.A., Lodder, W.J., Bouwknegt, M., de Roda Husman, A.M., 2007. Increased hepatitis $\mathrm{E}$ virus prevalence on Dutch pig farms from 33 to $55 \%$ by using appropriate internal quality controls for RT-PCR. J Virol Methods. 143, 112116.

Schielke, A., Sachs, K., Lierz, M., Appel, B., Jansen, A., Johne, R., 2009. Detection of hepatitis E virus in wild boars of rural and urban regions in Germany and whole genome characterization of an endemic strain. Virol J. 6, 58. Med Virol. 65, 282-292.

Seminati, C., Mateu, E., Peralta, B., de Deus, N., Martin, M., 2008. Distribution of hepatitis $\mathrm{E}$ virus infection and its prevalence in pigs on commercial farms in Spain. Vet J. 175, 130-132.

Tam, A.W., Smith, M.M., Guerra, M.E., Huang, C.C., Bradley, D.W., Fry, K.E., Reyes, G.R., 1991. Hepatitis E virus (HEV): molecular cloning and sequencing of the full-length viral genome. Virology. 185, 120-131.

Wichmann, O., Schimanski, S., Koch, J., Kohler, M., Rothe, C., Plentz, A., Jilg, W., Stark, K., 2008. Phylogenetic and case-control study on hepatitis E virus infection in Germany. J Infect Dis. 198, 1732-1741.

Zafrullah, M., Ozdener, M.H., Panda, S.K., Jameel, S., 1997. The ORF3 protein of hepatitis $E$ virus is a phosphoprotein that associates with the cytoskeleton. $J$ Virol. 71, 9045-9053. 
Fig. 1: Distribution of optical density (OD) values for the negative and positive 302 controls as determined by the TiHo-ELISA and definition of the cut-off value. Given are the cumulated values of the four negative controls and the values of positive control A and positive control B which have been tested up to 27 times in duplicate; the dot represents an outlier; dotted line: cut-off value 0.386 .

Table 1: Overview of reactivity of the pig sera in the TiHo-ELISA from the different federal states of Germany. Results comprise the total number of positive sera as well as the total number of infected farms (n. a.: not available).

Table 2: Overview of the different age groups of animals tested positively for HEV-

314 specific antibodies in the TiHo-ELISA.

Table 3: Comparison of results for 321 randomly selected pig sera from Germany obtained by two different antibody ELISA tests.

Table 4: Comparison of results for 23 randomly selected sera from German pigs obtained by three different HEV-antibody assays. 
Table 1: Overview of reactivity of the pig sera in the TiHo-ELISA from the different federal states of Germany. Results comprise the total number of positive sera as well as the total number of infected farms (n. a.: not available).

\begin{tabular}{|c|c|c|c|c|c|c|c|c|c|c|c|c|}
\hline $\begin{array}{l}\text { Federal } \\
\text { state }\end{array}$ & $\begin{array}{l}\text { Schleswig- } \\
\text { Holstein }\end{array}$ & $\begin{array}{l}\text { Mecklenburg- } \\
\text { Western } \\
\text { Pomerania }\end{array}$ & $\begin{array}{l}\text { Lower } \\
\text { Saxony }\end{array}$ & Brandenburg & $\begin{array}{c}\text { Saxony- } \\
\text { Anhalt }\end{array}$ & $\begin{array}{c}\text { North } \\
\text { Rhine- } \\
\text { Westphalia }\end{array}$ & Thuringia & Saxony & $\begin{array}{l}\text { Rhineland- } \\
\text { Palatinate }\end{array}$ & Bavaria & $\begin{array}{c}\text { Baden- } \\
\text { Württemberg }\end{array}$ & total \\
\hline $\begin{array}{c}\text { Total } \\
\text { number of } \\
\text { investigated } \\
\text { sera }\end{array}$ & 151 & 45 & 159 & 59 & 53 & 174 & 50 & 50 & 88 & 123 & 120 & 1072 \\
\hline $\begin{array}{l}\text { Number of } \\
\text { anti-HEV- } \\
\text { antibody } \\
\text { positive } \\
\text { sera }\end{array}$ & 106 & 7 & 25 & 24 & 30 & 74 & 26 & 28 & 49 & 87 & 78 & 534 \\
\hline$\%$ & 70.2 & 15.6 & 15.7 & 40.7 & 56.6 & 42.5 & 52.0 & 56.0 & 55.7 & 70.7 & 65.0 & 49.8 \\
\hline $\begin{array}{c}\text { Total } \\
\text { number of } \\
\text { investigated } \\
\text { farms }\end{array}$ & 18 & 11 & 10 & n. a. & 11 & 17 & 10 & 21 & 21 & 10 & 13 & 142 \\
\hline $\begin{array}{c}\text { Number of } \\
\text { farms with } \\
\text { anti-HEV- } \\
\text { antibody } \\
\text { positive } \\
\text { pigs }\end{array}$ & 13 & 3 & 6 & n. a. & 10 & 13 & 7 & 18 & 18 & 10 & 13 & 111 \\
\hline$\%$ & 72.2 & 27.3 & 60.0 & n. a. & 90.9 & 76.5 & 70.0 & 85.7 & 85.7 & 100.0 & 100.0 & 78.2 \\
\hline
\end{tabular}


Table 2: Overview of the different age groups of animals tested positively for HEVspecific antibodies in the TiHo-ELISA.

\begin{tabular}{|c|c|c|c|c|c|c|c|c|c|c|c|c|}
\hline & $\begin{array}{c}\text { North } \\
\text { Rhine- } \\
\text { Westphalia }\end{array}$ & $\begin{array}{c}\text { Number of } \\
\text { anti-HEV } \\
\text { positive } \\
\text { animals }\end{array}$ & $\%$ & Brandenburg & $\begin{array}{c}\text { Number of } \\
\text { anti-HEV } \\
\text { positive } \\
\text { animals }\end{array}$ & $\%$ & $\begin{array}{l}\text { Lower } \\
\text { Saxony }\end{array}$ & $\begin{array}{c}\text { Number } \\
\text { of anti- } \\
\text { HEV } \\
\text { positive } \\
\text { animals }\end{array}$ & $\%$ & $\begin{array}{c}\text { Total } \\
\text { number of } \\
\text { investigated } \\
\text { sera }\end{array}$ & $\begin{array}{c}\text { Total } \\
\text { number of } \\
\text { anti-HEV } \\
\text { positive } \\
\text { animals }\end{array}$ & $\%$ \\
\hline piglets & 27 & 13 & 48.1 & - & - & & 74 & 4 & 5.4 & 101 & 17 & 16.8 \\
\hline fatteners & 27 & 15 & 55.6 & 15 & 5 & 33.3 & 54 & 10 & 18.5 & 96 & 30 & 31.3 \\
\hline sows & - & - & & 15 & 12 & 80.0 & 31 & 11 & 35.5 & 46 & 23 & 50.0 \\
\hline boars & 6 & 4 & 66.7 & 15 & 6 & 40.0 & - & - & & 21 & 10 & 47.6 \\
\hline total & 60 & 32 & 53.3 & 45 & 23 & 51.1 & 159 & 25 & 15.7 & 264 & 80 & 30.3 \\
\hline
\end{tabular}


Table 3: Comparison of results for 321 randomly selected pig sera from Germany obtained by two different antibody ELISA tests.

\begin{tabular}{|c|c|c|c|c|}
\hline & \multicolumn{2}{|c|}{ TiHo-ELISA } & \\
\hline & & positive & negative & \\
\hline \multirow{2}{*}{ 它 } & positive & 104 & 104 & $\Sigma 208$ \\
\hline & negative & 37 & 76 & $\Sigma 113$ \\
\hline & & $\Sigma 141$ & $\Sigma 180$ & \\
\hline
\end{tabular}


Table 4: Comparison of results for 23 randomly selected sera from German pigs obtained by three different HEV-antibody assays.

\begin{tabular}{|c|c|c|c|c|}
\hline $\begin{array}{c}\text { no. of } \\
\text { serum }\end{array}$ & origin & TiHo-ELISA & Axiom-ELISA & recomBlot \\
\hline 1 & Schleswig-Holstein & positive & positive & positive \\
\hline 2 & Rhineland-Palatinate & positive & positive & positive \\
\hline 3 & Rhineland-Palatinate & positive & positive & positive \\
\hline 4 & Baden-Wuerttemberg & positive & positive & equivocal \\
\hline 5 & North Rhine-Westphalia & positive & positive & equivocal \\
\hline 6 & Rhineland-Palatinate & positive & positive & equivocal \\
\hline 7 & Brandenburg & positive & negative & negative \\
\hline 8 & Saxony-Anhalt & positive & negative & negative \\
\hline 9 & Rhineland-Palatinate & positive & negative & positive \\
\hline 10 & Rhineland-Palatinate & positive & negative & equivocal \\
\hline 11 & Bavaria & positive & negative & equivocal \\
\hline 12 & Rhineland-Palatinate & positive & negative & equivocal \\
\hline 13 & Rhineland-Palatinate & negative & negative & negative \\
\hline 14 & Rhineland-Palatinate & negative & negative & negative \\
\hline 15 & Rhineland-Palatinate & negative & negative & negative \\
\hline 16 & Rhineland-Palatinate & negative & negative & negative \\
\hline 17 & Saxony & negative & positive & positive \\
\hline 18 & Saxony & negative & positive & negative \\
\hline 19 & Thuringia & negative & positive & negative \\
\hline 20 & Brandenburg & negative & positive & negative \\
\hline 21 & Saxony-Anhalt & negative & positive & negative \\
\hline 22 & Rhineland-Palatinate & negative & positive & negative \\
\hline 23 & Rhineland-Palatinate & negative & positive & negative \\
\hline
\end{tabular}




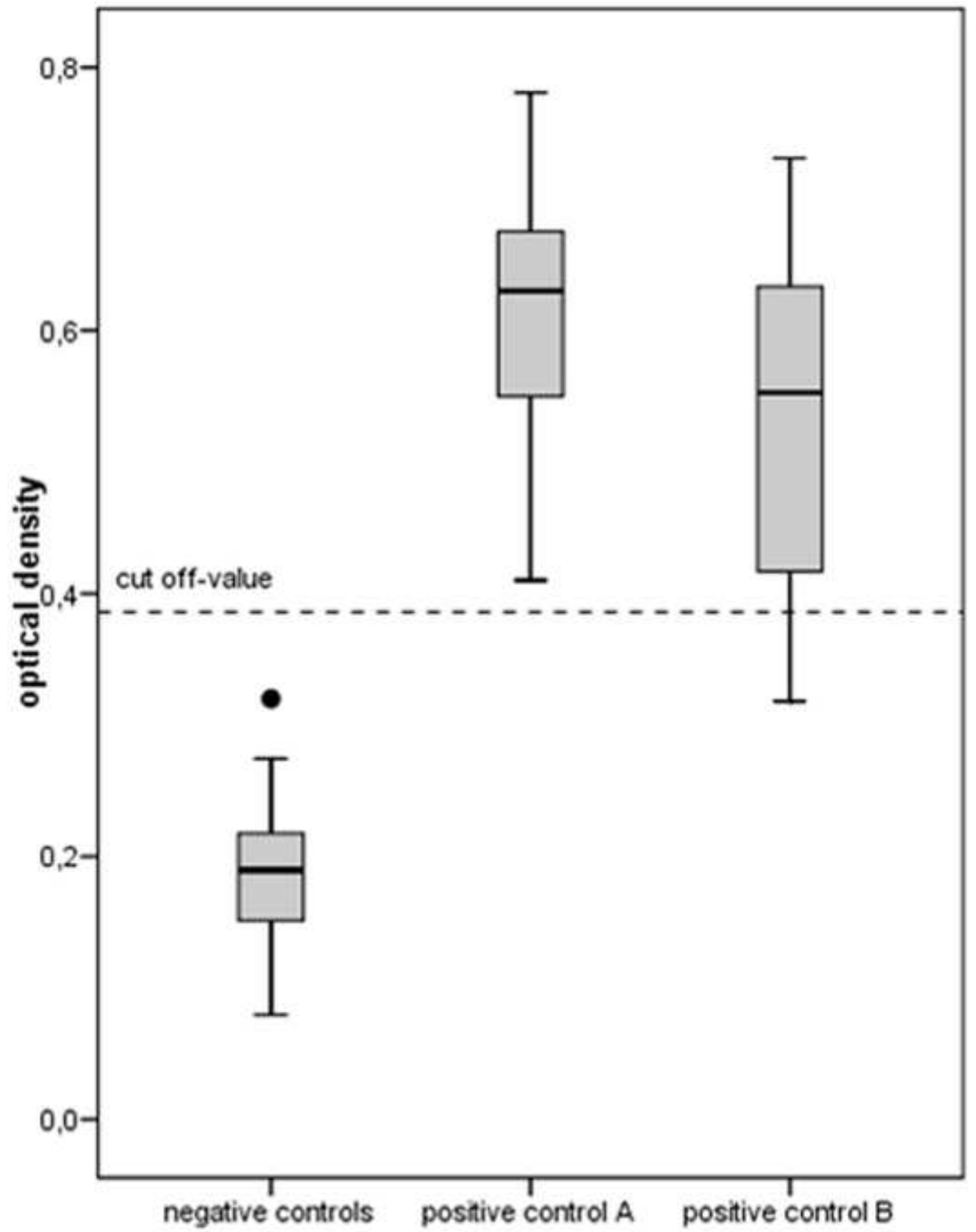

Page 18 of 18 